\title{
Anti-DNA Autoantibody-producing Hybridomas of Normal Human Lymphoid Cell Origin
}

Ewa Cairns, Jonathan Block, and David A. Bell

Departments of Medicine and Microbiology and Immunology,

University of Western Ontario, University Hospital, Rheumatic

Diseases Unit, London, Ontario, Canada, N6A 5 A5

bstract. Fusion of human myeloma cell line GM 4672 and tonsillar lymphoid cells from a normal donor resulted in 13 primary hybridomas, which produced IgM anti-single-stranded DNA (ssDNA) antibodies, as determined in enzyme-linked immunosorbent assay. Nine of these primary hybridomas have been cloned and a total of 34 clones were obtained. Supernatants of these cloned hybridomas were tested for binding to ssDNA, native DNA, RNA, low molecular weight supernatant DNA, polydeoxyguanylate-polydeoxycitidylate, polydeoxyadenylate-thymidylate sodium salt, and cardiolipin. Supernatants from all clones but one showed polyspecificity when reacting with the antigens tested. That the clones were true hybridomas rather than transformed lymphoid cells was evidenced by IgM anti-DNA antibody secretion, karyotype analysis, and HLA typing. These studies imply that immunoglobulin genes encoding for anti-DNA autoantibodies with a spectrum of nucleic acid specificities similar to systemic lupus erythematosus, exist among normal B lymphocytes.

\section{Introduction}

The presence of serum anti-DNA antibodies is characteristic of murine and human systemic lupus erythematosus (SLE) ${ }^{1}$

Received for publication 28 December 1983 and in revised form 7 May 1984.

1. Abbreviations used in this paper: EBV, Epstein-Barr virus; ELISA, enzyme-linked immunosorbent assay; FCS, fetal calf serum; GM, growth medium; HAT, hypoxanthine-aminopterine-thymidine; PFRM, postfusion recovery medium; poly(dA-dT), polydeoxyadenylate-thymidylate sodium salt; poly dG.poly dC, polydeoxyguanylate-polydeoxycitidylate; RT, room temperature; SFM, serum-free medium; SLE, systemic lupus erythematosus; S/N DNA, supernatant low molecular weight DNA produced by thymocytes of New Zealand black/ white mice in vitro; ssDNA, single-stranded DNA.

J. Clin. Invest.

(c) The American Society for Clinical Investigation, Inc. 0021-9738/84/09/0880/08 $\$ 1.00$

Volume 74, September 1984, 880-887
$(1,2)$. Such antibodies have been shown to participate in the immune complex nephritis associated with this disorder (3). In addition, while antibodies to single-stranded DNA (ssDNA) also occur in SLE, they are frequently seen in several other conditions (4), however, antibodies to double-stranded DNA are considered unique to SLE (5).

We and others have reported on the spontaneous occurrence of anti-DNA antibodies produced in vitro with the spleen cells of young preautoimmune New Zealand black/New Zealand white mice as well as some nonautoimmune normal strains (6). In humans, the circulating lymphocytes of normal individuals may occasionally be stimulated to produce anti-DNA antibody in vitro, although a spontaneous in vitro anti-DNA antibody response has been noted with the circulating lymphocytes of SLE patients (7). However, spontaneous in vitro production of anti-DNA antibodies is not restricted to cultures from SLE patients. We have been able to detect anti-DNA antibodies frequently in culture supernatants from nonstimulated tonsillar lymphoid cells of normal individuals (8). This suggests that normal tonsillar lymphoid cells exist in a state of preactivation or differentiation that may be similar to that seen with the circulating B lymphocytes of SLE patients.

The fusion of normal tonsillar lymphocytes with myeloma cells to produce human-human anti-DNA hybridomas should provide a unique system for comparison with hybridomas of SLE origin such as those that have been recently reported by Shoenfeld et al. (9). This paper describes the production of monoclonal anti-DNA antibodies derived from normal tonsillar lymphocytes. These monoclonal anti-nucleic acid antibodies showed binding characteristics similar to the anti-DNA antibodies present in SLE serum as well as the monoclonal antibodies obtained from SLE circulating lymphocytes (10).

\section{Methods}

Preparation of donor's lymphoid cells. Palatine tonsils were obtained from a normal female donor (age 7). This patient's serum exhibited normal immunoglobulin levels, and lacked antibodies to ss-DNA and double-stranded DNA by enzyme-linked immunosorbent assay (ELISA). Tonsillar tissue was cut into small pieces, homogenized with a Dounce homogenizer in RPMI 1640, pH 7.4 (Gibco Laboratories, Grand Island, NY) and lymphoid cells were purified by centrifugation on a 
Ficoll-Hypaque density gradient (specific gravity, 1.08) (Ficoll 400 , Pharmacia Fine Chemicals AB, Uppsala, Sweden; Hypaque, Winthrop Laboratories, Aurora, Ontario) according to Boyum (11). Cells were washed three times in RPMI 1640 by resuspension after centrifugation at $300 \mathrm{~g}$ for $8 \mathrm{~min}$. All centrifugation was done at $20^{\circ} \mathrm{C}$. The final pellet was resuspended in serum-free medium (SFM) to the cell concentration needed for fusion. SFM contained RPMI 1640 supplemented with $1 \% 200 \mathrm{mM}$ L-glutamine (Gibco Laboratories), $1 \% 10$ mM sodium pyruvate (M.A. Bioproducts, Walkersville, MD), $1 \% 2.5$ M $N$-2-hydroxyethylpiperazine- $N$-2-ethanesulfonic acid (Hepes) (Gibco Laboratories), $1.25 \%$ of a solution containing $10,000 \mathrm{U} / \mathrm{ml}$ penicillin, $10,000 \mu \mathrm{g} / \mathrm{ml}$ streptomycin (Gibco Laboratories), $0.5 \% 10 \mathrm{mM}$ nonessential amino acids (M.A. Bioproducts), and $0.2 \% 50 \mathrm{mg} / \mathrm{ml}$ gentamycin (Schering Corp., Kenilworth, NJ).

Human myeloma cell line. The hypoxanthine phosphoribosyl transferase-deficient, hypoxanthine-aminopterine-thymidine (HAT) sensitive, $\mathrm{IgG}_{2} \kappa$ producer mutant cell line GM 4672 was obtained from the Institute for Medical Research (Camden, NJ). Myeloma cells were cultured in RPMI 1640 supplemented with $1 \% 200 \mathrm{mM}$ L-glutamine, $10 \%$ fetal calf serum (FCS) (Gibco Laboratories), which was heat inactivated for $30 \mathrm{~min}$ at $56^{\circ} \mathrm{C}$, and $1 \times 10^{-4} \mathrm{M}$ 6-thioguanine (Sigma Chemical Co., St. Louis, MO). $5 \mathrm{~d}$ before fusion, myeloma cells were staged up into $75-\mathrm{cm}^{2}$ polystyrene flasks (Corning Glass Works, Corning Medical and Scientific, Corning, NY) without 6-thioguanine. Before fusion, cells were washed twice by pelleting the cells at $200 \mathrm{~g}$ for $10 \mathrm{~min}$ and gently resuspending them in SFM. Cells were finally resuspended in the desired volume of SFM.

Cell fusion. Fusion was performed according to the procedure described by Shoenfeld et al. (9), with minor modifications as follows. Cells were mixed at ratios 1:1 and 5:1 (lymphoid cells/myeloma cells), co-pelleted by centrifugation $(200 \mathrm{~g}, 10 \mathrm{~min})$, and treated with $0.5 \mathrm{ml}$ 44.4\% polyethylene glycol 1450 (J. T. Baker Chemical Co., Phillipsburg, $\mathrm{NY}$ ) in SFM. After gentle resuspension, the pelleted cells were spun down at $300 \mathrm{~g}$ for $3 \mathrm{~min}$, resuspended in $10 \mathrm{ml} \mathrm{SFM}$, and pelleted again at $200 \mathrm{~g}$ for $5 \mathrm{~min}$. Finally, cells were resuspended in postfusion recovery medium (PFRM) and cultured for $24 \mathrm{~h}$ at $37^{\circ} \mathrm{C}$ in a humidified $5 \% \mathrm{CO}_{2}$ atmosphere. PFRM consisted of RPMI 1640 supplemented with $1 \% 200 \mathrm{mM}$ L-glutamine and $1 \%$ of a solution containing 10,000 $\mathrm{U} / \mathrm{ml}$ penicillin, $10,000 \mu \mathrm{g} / \mathrm{ml}$ streptomycin, $1 \% 100 \mathrm{mM}$ sodium pyruvate, $0.5 \% 10 \mathrm{mM}$ nonessential amino acids, $15 \%$ heat-inactivated FCS, and $0.2 \% 50 \mathrm{mg} / \mathrm{ml}$ gentamycin.

Postfusion hybridoma cultures. After $24 \mathrm{~h}$ of incubation in PFRM, cells were spun down at $200 \mathrm{~g}$ for $5 \mathrm{~min}$ and resuspended in HAT medium (12), supplemented with 5\% NCTC 109 (M.A. Bioproducts). Cells were dispensed at $4 \times 10^{5}$ cells/well in $2 \mathrm{ml}$ on 24-well Costar trays (Costar, Data Packaging, Cambridge, MA) and at $1 \times 10^{5}$ cells/ well and $2 \times 10^{5}$ cells/well in $0.2 \mathrm{ml}$ on 96-well Costar trays and cultured at $37^{\circ} \mathrm{C}$ in a humidified $5 \% \mathrm{CO}_{2}$ atmosphere. One-half the HAT media was removed and replenished weekly. Positive growth was scored after 4 wk. 24-well tray supernatants were then screened for anti-DNA antibodies by using an ELISA, while 96-well tray hybridomas were transferred to 24-well trays for $7 \mathrm{~d}$ before screening for anti-DNA antibody. Anti-DNA antibody-producing hybridomas were cloned by limiting dilution at 2 cells/well in $0.2 \mathrm{ml}$ of growth medium (GM); and the cells were left unfed for 4 wk. Growing cells were then transferred to 24-well trays and after $10 \mathrm{~d}$ were tested for anti-DNA antibody production. GM contained RPMI 1640 supplemented with $1 \% 200 \mathrm{mM}$ L-glutamine, $1 \% 100 \mathrm{mM}$ sodium pyruvate, $0.5 \% 10 \mathrm{mM}$ nonessential amino acids, 5\% NCTC 109, and 1\% of a solution containing $10,000 \mathrm{U} / \mathrm{ml}$ penicillin, $10,000 \mu \mathrm{g} / \mathrm{ml}$ streptomycin, and
$12 \%$ heat-inactivated FCS. Positive clones for anti-DNA antibody were transferred to $25-\mathrm{cm}^{2}$ culture flasks and cultivated in GM. Cultures were supplied with fresh GM medium after $10 \mathrm{~d}$ of growth and within the next $10 \mathrm{~d}$ they were transferred into $75-\mathrm{cm}^{2}$ flasks.

ELISA. Polystyrene wells of 96 round-bottomed Cooke microtiter plates (Dynatech Laboratories, Inc., Dynatech Corp., Alexandria, VA) were coated with $50 \mu \mathrm{l}$ of $50 \mu \mathrm{g} / \mathrm{ml}$ poly-L-lysine (Sigma Chemical Co.) in $0.1 \mathrm{M}$ Tris-HCl, $\mathrm{pH}$ 7.4. After $1 \mathrm{~h}$ of incubation at room temperature (RT) wells were washed three times with $0.1 \mathrm{M}$ Tris- $\mathrm{HCl}$, $\mathrm{pH} 7.4$, and $50 \mu \mathrm{l}$ of antigen was pipetted into the wells. Nucleic acid antigen was left in the wells for $1 \mathrm{~h}$ at RT. Alternate wells served as

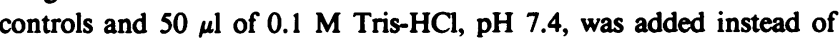
antigen. When cardiolipin was used as the antigen, it was directly added to the wells without prior poly-L-lysine treatment, and incubated overnight at $4^{\circ} \mathrm{C}$.

The following antigens were used in ELISA: $10 \mu \mathrm{g} / \mathrm{ml}$ calf thymus DNA (Millipore Corporation, Freehold, NJ) in $0.1 \mathrm{M}$ Tris- $\mathrm{HCl}$, $\mathrm{pH}$ 7.4; $10 \mu \mathrm{g} / \mathrm{ml}$ single-stranded calf thymus DNA in $0.1 \mathrm{M}$ Tris- $\mathrm{HCl}$, pH 7.4, prepared as described by Doty et al. (13); $10 \mu \mathrm{g} / \mathrm{ml}$ polydeoxyguanylate-polydeoxycytidylate (poly dG.poly dC) (Miles Laboratories, Inc., Kankakee, IL) in $0.1 \mathrm{M}$ Tris- $\mathrm{HCl}, \mathrm{pH} 7.4 ; 10 \mu \mathrm{g} / \mathrm{ml}$ polydeoxyadenylate-thymidylate sodium salt (poly[dA-dT]) (Miles Laboratories, Inc.) in $0.1 \mathrm{M}$ Tris- $\mathrm{HCl}, \mathrm{pH} 7.4 ; 10 \mu \mathrm{g} / \mathrm{ml}$ low molecular weight supernatant DNA (S/N DNA) obtained from New Zealand

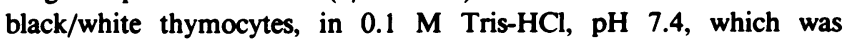
prepared as previously described (14); $20 \mu \mathrm{g} / \mathrm{ml}$ cardiolipin (CalbiochemBehring Corp., American Hoechst Corp., La Jolla, CA) in phosphatebuffered saline (PBS), pH 7.4 (Gibco Laboratories); and $10 \mu \mathrm{g} / \mathrm{ml}$ RNA from yeast (Sigma Chemical Co.) in $0.1 \mathrm{M}$ Tris-HCl, pH 7.4. Antigen-coated wells were washed three times with washing buffer 0.1 $\mathrm{M}$ Tris- $\mathrm{HCl}, \mathrm{pH} 7.4$, containing $0.1 \%$ bovine serum albumin (BSA) (Gibco Laboratories) and $0.05 \%$ Tween 20 (Sigma Chemical Co.). The

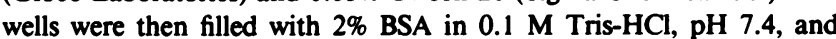
incubated for $2 \mathrm{~h}$ at RT. After one wash with washing buffer, $50 \mu \mathrm{l} /$ well of hybridoma supernatant was added and the tray was incubated overnight at $4^{\circ} \mathrm{C}$. After five washings with washing buffer, $50 \mu \mathrm{l}$ of either goat anti-human IgM alkaline phosphatase conjugate, $1 \mu \mathrm{g} / \mathrm{ml}$ (Cordis Laboratories, Inc., Miami, FL), or goat anti-human IgG alkaline phosphatase conjugate, $1 \mu \mathrm{g} / \mathrm{ml}$ (Cordis Laboratories, Inc.) diluted with $1 \%$ BSA, $2 \%$ bovine gammaglobulin (Sigma Chemical Co.) in $0.1 \mathrm{M}$ Tris- $\mathrm{HCl}$, pH 7.4, was added to the wells and incubated for $3 \mathrm{~h}$ at RT. Five further washings of the wells with washing bufic were followed by addition of $50 \mu \mathrm{l}$-nitrophenyl phosphate, $1 \mathrm{mz} / \mathrm{ml}$ (Sigma Chemical Co.) in diethanolamine buffer, pH 9.8. After $30 \mathrm{~min}$ of incubation with the substrate at $37^{\circ} \mathrm{C}$, the enzymatic reaction was stopped with $25 \mu \mathrm{l} /$ well of $3 \mathrm{M} \mathrm{NaOH}$. Optical densities were read in a Titertek Multiskan (Dynatech Laboratories, Inc.) at $\mathbf{4 0 5} \mathrm{nm}$. Detection of anti-ssDNA antibody and anti-DNA antibody by ELISA was specific since $1 \mu \mathrm{g}$ of ssDNA or DNA inhibited $>50 \%$ and $5 \mu \mathrm{g}$ completely inhibited the binding of SLE serum antibodies or hybridoma supernatant antibody to the antigen-coated wells. The binding of antibodies from SLE sera or hybridoma supernatant was also abolished in ELISA after treatment of the DNA-coated wells with DNase I. In addition to these studies, which indicated the binding directed to DNA, none of the positive hybridoma supernatants showed any binding to the unrelated antigens ovalbumin, keyhole limpet hemocyanin, 2,4-dinitrophenol, or human serum albumin. IgM concentrations in the hybridoma supernatants were determined by an ELISA method in which the $\mathrm{OD}_{405}$ units were converted to the absolute values of IgM from a standard curve with binding of affinity-purified human IgM (Cappel 
Laboratories, Cochranville, PA), to rabbit anti-human ( $\mu$-chain specific, Dakopatts, Glostrup, Denmark)-coated wells. Myeloma GM 4672 supernatant did not bind in this assay, nor did $1 \mu \mathrm{g} / \mathrm{ml}$ of human IgG (Cappel Laboratories).

Karyotyping. Rapidly proliferating cells were obtained by seeding $1 \times 10^{6}$ cells in $5 \mathrm{ml}$ of $\mathrm{GM}$ and culturing for $48 \mathrm{~h}$. Then $50 \mu \mathrm{l}$ of 10 $\mu \mathrm{g} / \mathrm{ml}$ Colcemid (Gibco Laboratories) was added and cultures were incubated for $35 \mathrm{~min}$. Cells were centrifuged at $200 \mathrm{~g}$ for $8 \mathrm{~min}$ and the pellet was resuspended in $4 \mathrm{ml}$ of $75 \mathrm{mM}$ potassium chloride. After incubation for $15 \mathrm{~min}$ at $37^{\circ} \mathrm{C}$, cells were recentrifuged, resuspended in $4 \mathrm{ml}$ of fixative (1:3 acetic acid/methanol), and left for 30 min at $4^{\circ} \mathrm{C}$. Cells were then washed twice in fixative and resuspended in $1 \mathrm{ml}$ of fixative. Two drops of the cell suspension were dispensed onto glass slides (ethanol washed and stored at minus $20^{\circ} \mathrm{C}$ ) and allowed to air dry. Slides were washed in saline, stained with $4 \%$ Giemsa (Fisher Scientific Co., Fair Lawn, NJ) in $6 \times 10^{-4} \mathrm{M}$ phosphate buffer, $\mathrm{pH}$ 6.8, destained in distilled water and mounted with Permount (Fisher Scientific Co.). Slides were examined under the light microscope and 50 karyotypes were scored.

HLA typing. Actively proliferating cells were washed twice with $\mathrm{GM}$, centrifuged for $8 \mathrm{~min}$ at $200 \mathrm{~g}$ and resuspended in $\mathrm{GM}$ at 2 $\times 10^{6} / \mathrm{ml}$. Terasaki (T-27) and Canadian Red Cross (NRLT 85-5) HLA typing trays were used for HLA typing by a microcytotoxicity assay as described by Terasaki et al. (15).

\section{Results}

Initial hybridization and antibody screening. After the myelomatonsillar lymphocyte fusion procedure 431 wells were seeded. Growth was observed in 110 wells (25.5\%). An ssDNA ELISA assay system was used to screen for hybridomas producing anti-DNA antibody, and 13 of 110 wells (11.8\%) were positive. Thus, positive wells for anti-ssDNA antibodies constituted $3 \%$ of the total 431 wells seeded. IgM and IgG levels were also quantitated by ELISA in hybridoma supernatants both positive and negative for anti-DNA antibodies. $85 / 110$ hybridoma supernatants were available for testing, of which 13 were positive and 72 were negative for anti-DNA antibody. Both positive and negative hybridoma supernatants contained IgM; eight contained only IgG. None of the latter showed binding to DNA. The IgM levels of the positive hybridoma supernatants ranged from 0.5 to $8 \mu \mathrm{g} / \mathrm{ml}$ but the anti-DNA antibodynegative hybridoma supernatants contained $<0.5 \mu \mathrm{g} / \mathrm{ml}$. Despite the lower levels of IgM in the negative hybridomas, the lack of binding to DNA was not a reflection of lack of sensitivity of the ELISA assay, since positive hybridoma supernatants showed binding when these were diluted, well within the range of IgM levels observed in the anti-DNA antibody-negative supernatants. The overall yield of anti-ssDNA antibody producing hybridomas is a function of both the probability of obtaining successful fusion and the probability that successful fusion will lead to anti-ssDNA antibody production. Table I suggests that these variables may depend on both the concentration of cells used in postfusion cultures and on the ratio of lymphocyte/myeloma cells used in the fusion. For any given fusion ratio of cells the probability of finding hybridomas after the 24-h postfusion recovery and 4-wk culture period was higher when the cells were cultured at $4 \times 10^{5}$ cells/well than at $1 \times 10^{5}$ cells/well; however, at the lower cell concentration $\left(10^{5}\right)$ there was a greater probability of detecting hybridomas that produce anti-ssDNA antibodies. Both the probability of fusion and anti-ssDNA antibody production also appear to depend on lymphocyte/myeloma ratio with a ratio of 1:1 producing the highest values $(87 \%$ for fusion; $21 \%$ for antissDNA antibody production). As indicated in Table $I$ the overall yield of anti-ssDNA antibody-producing hybridomas (6.7\%) was found with 1:1 cell ratio for fusion and a $4 \times 10^{5}$ cells/well for culturing.

The 13 positive supernatants for anti-ssDNA antibodies were also tested for binding to undenatured DNA. All except hybridomas KIM 3, KIM 8, and KIM 11 reacted with DNA (Fig. 1). Binding of supernatants to ssDNA was greater than to DNA except for KIM 12, which reacted equally well with both ssDNA and DNA.

Cloning of primary hybridomas. Cloning was successful in 9/13 primary hybridomas and yielded 34 clones. Four of these

Table I. Growth of Hybridomas and Anti-ssDNA Antibody Production

\begin{tabular}{|c|c|c|c|c|c|c|}
\hline Lymphocyte/myeloma cell ratio & $5: 1$ & & & $1: 1$ & & \\
\hline Cells/well & $4 \times 10^{5}$ & $2 \times 10^{5}$ & $1 \times 10^{5}$ & $4 \times 10^{5}$ & $2 \times 10^{5}$ & $1 \times 10^{5}$ \\
\hline $\begin{array}{l}\text { Fraction and percent of wells positive } \\
\text { for hybridoma growth }\end{array}$ & $\begin{array}{l}14 / 43 \\
(33 \%)\end{array}$ & $\begin{array}{l}2 / 13 \\
(15 \%)\end{array}$ & $\begin{array}{l}8 / 69 \\
(12 \%)\end{array}$ & $\begin{array}{l}39 / 45 \\
(87 \%)\end{array}$ & $\begin{array}{l}14 / 107 \\
(13 \%)\end{array}$ & $\begin{array}{l}33 / 154 \\
(21 \%)\end{array}$ \\
\hline $\begin{array}{l}\text { Fraction and percent of growth- } \\
\text { positive wells also positive for anti- } \\
\text { ssDNA antibody. }\end{array}$ & $\begin{array}{l}1 / 14 \\
(7 \%)\end{array}$ & $\begin{array}{l}0 / 2 \\
(0 \%)\end{array}$ & $\begin{array}{l}1 / 8 \\
(12.5 \%)\end{array}$ & $\begin{array}{c}3 / 39 \\
(7.7 \%)\end{array}$ & $\begin{array}{l}1 / 14 \\
(7 \%)\end{array}$ & $\begin{array}{r}7 / 33 \\
(21 \%)\end{array}$ \\
\hline $\begin{array}{l}\text { Percent of all seeded wells positive } \\
\text { for both hybridoma growth and } \\
\text { anti-ssDNA antibody production }\end{array}$ & $2.3 \%$ & $0 \%$ & $1.5 \%$ & $6.7 \%$ & $0.9 \%$ & $4.4 \%$ \\
\hline
\end{tabular}




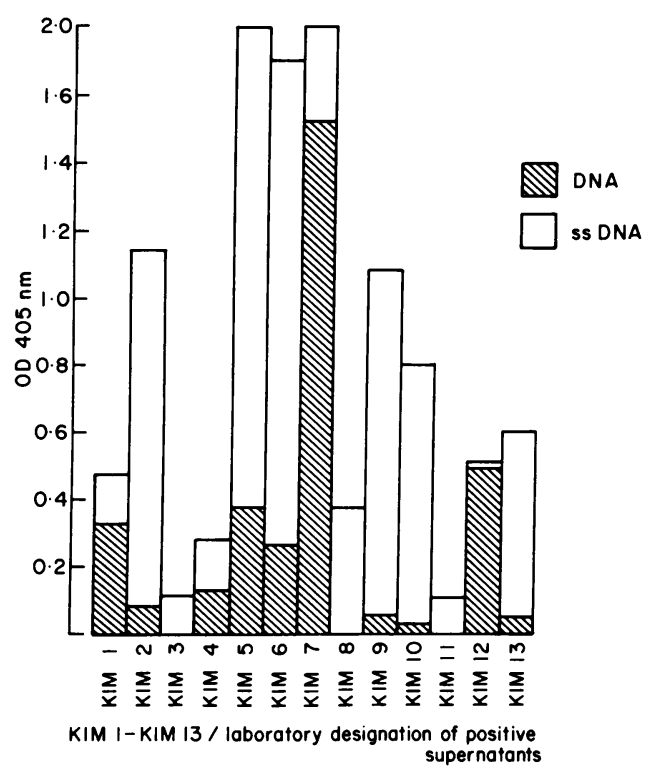

Figure 1. Binding to DNA and ssDNA of antibody from supernatants obtained during the initial screening by ELISA.

13 primary hybridomas (KIM 2, KIM 3, KIM 6, and KIM 8) were not cloned. Fig. 2 shows the binding of the supernatants from 34 clones to poly(dA-dT), poly dG - poly dC, low molecular weight (150 base pairs)S/NDNA, RNA, cardiolipin, ssDNA, and DNA. All supernatants except KIM 11.1-KIM 11.8 showed polyspecificity in reacting with the antigens used. The different specificities of the antibodies produced by a given hybridoma culture can be characterized by the ratio of antibody reactivity with each antigen to reactivity with a reference antigen. The reference antigen was chosen as ssDNA, since it was universally reactive with all the hybridoma supernatants tested. Table II lists for all clones the ratio of antibody reactivity with each antigen to reactivity with ssDNA. From the data in Fig. 2 and Table II the relative reactivity of the clones for certain nucleic acid antigens allowed these clones to be separated into eight different groups. Table III summarizes these groups and the range of their reactivity ratios. Groups 1-3 show no binding to double-stranded antigens, while groups 4-8 do. Groups 2 and 3 bind cardiolipin in addition to ssDNA. Groups 7a and b (KIM 7 and KIM 1 clones, respectively) appear very similar in the spectrum of their reactivity ratios. Group 8 reacts with RNA but not with DNA.

All anti-ssDNA antibodies were of the IgM isotype, as determined by the use of a goat anti-human IgM antibody in ELISA. No antibodies to any of the seven antigens used were detected in the supernatant of the myeloma cell cultures alone, using anti-human IgG and IgM antibodies.

HLA typing and karyotype analysis. The anti-DNA antibody-producing clones KIM 4.3 and KIM 4.5 were subjected to HLA typing. These cloned hybridomas expressed A-2,3,23/ B-12,15,7,22 human leukocyte antigens; however, only HLA

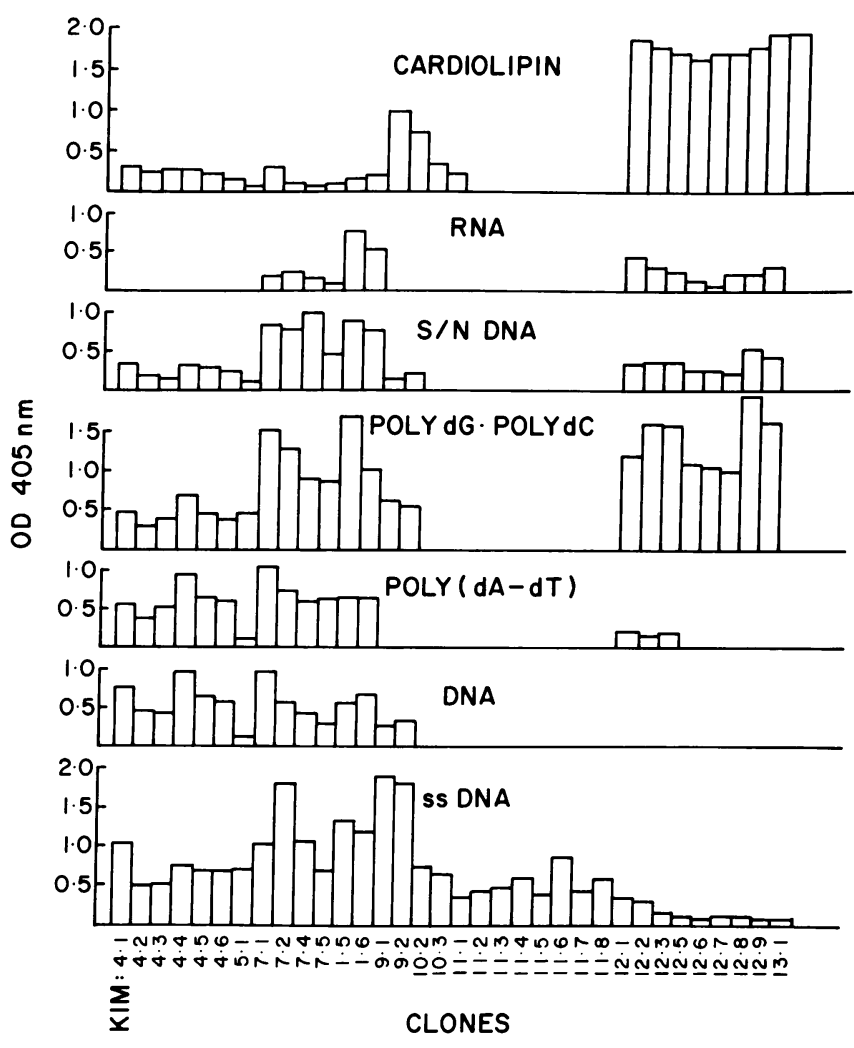

Figure 2. Binding of supernatant antibodies from cloned hybridomas to ssDNA, DNA, poly(dA-dT), poly dG • poly dC, S/N DNA, RNA, and cardiolipin.

A-2,3/B-12,15 were detected on the GM 4672 myeloma line cells.

Karyotyping of KIM 4 clones was also performed. Heterogeneity of the cells within the individual clones was observed with respect to the chromosomal number (Table IV). Hyperdiploid, diploid, and hypodiploid cells were found within each clone. Five of the clones KIM 4.2-KIM 4.6 contained large percentages of hypodiploid cells. The most frequent hypodiploid chromosomal number in all clones was 44 . The lowest number of chromosomes was found to be $32,30,28,31,41$, and 36 for KIM 4.1-KIM 4.6, respectively. The highest number of chromosomes scored was 92 for all clones; except KIM 4.1 and KIM 4.4 had the highest chromosomal counts of 90 and 86 , respectively.

\section{Discussion}

Our results demonstrate that fusion of unstimulated tonsillar lymphocytes from a normal donor with the myeloma cell line GM 4672 produced hybridomas that secrete anti-DNA antibodies. This patient did not have any measurable levels of anti-DNA antibody in her serum, had normal immunoglobulin levels, and had no family history of a connective tissue 
Table II. Ratio of Antibody Reactivities (OD $405 \mathrm{~nm}$ ) with Each Antigen to the Reactivity with the ssDNA Reactivity Ratios

\begin{tabular}{|c|c|c|c|c|c|c|}
\hline Clone & Cardiolipin/ssDNA & RNA/ssDNA & S/N DNA/ssDNA & poly dG. poly dC/ssDNA & poly(dA-dT)/ssDNA & DNA/ssDNA \\
\hline \multicolumn{7}{|l|}{ KIM: } \\
\hline 4.1 & 0.3 & 0 & 0.3 & 0.4 & 0.5 & 0.7 \\
\hline 4.2 & 0.4 & 0 & 0.4 & 0.5 & 0.7 & 0.8 \\
\hline 4.3 & 0.5 & 0 & 0.3 & 0.5 & 0.9 & 0.7 \\
\hline 4.4 & 0.3 & 0 & 0.5 & 0.8 & 1.3 & 1.3 \\
\hline 4.5 & 0.3 & 0 & 0.5 & 0.6 & 1.0 & 0.9 \\
\hline 4.6 & 0.2 & 0 & 0.4 & 0.5 & 0.9 & 0.8 \\
\hline 5.1 & 0.1 & 0 & 0.2 & 0.5 & 0.2 & 0.2 \\
\hline 7.1 & 0.3 & 0.2 & 0.8 & 2.2 & 1.1 & 1.0 \\
\hline 7.2 & 0.1 & 0.1 & 0.4 & 0.7 & 0.4 & 0.3 \\
\hline 7.4 & 0.05 & 0.1 & 0.9 & 0.8 & 0.6 & 0.4 \\
\hline 7.5 & 0.1 & 0.1 & 0.6 & 1.1 & 0.9 & 0.4 \\
\hline 1.5 & 0.1 & 0.6 & 0.6 & 1.3 & 0.5 & 0.4 \\
\hline 1.6 & 0.2 & 0.5 & 0.6 & 0.8 & 0.6 & 0.6 \\
\hline 9.1 & 0.5 & 0 & 0.05 & 0.3 & 0 & 0.1 \\
\hline 9.2 & 0.4 & 0 & 0.1 & 0.3 & 0 & 0.1 \\
\hline 10.2 & 0.5 & 0 & 0 & 0 & 0 & 0 \\
\hline 10.3 & 0.3 & 0 & 0 & 0 & 0 & 0 \\
\hline 11 & 0 & 0 & 0 & 0 & 0 & 0 \\
\hline 12.1 & 5.4 & 1.1 & 0.9 & 3.3 & 0.4 & 0 \\
\hline 12.2 & 6.0 & 1.0 & 1.2 & 5.2 & 0.3 & 0 \\
\hline 12.3 & 11.7 & 1.7 & 2.3 & 10.3 & 1.0 & 0 \\
\hline 12.5 & 16.5 & 1.0 & 2.5 & 11.0 & 0 & 0 \\
\hline 12.6 & 17.5 & 0.5 & 1.5 & 10.5 & 0 & 0 \\
\hline 12.7 & 17.5 & 2.0 & 2.0 & 9.5 & 0 & 0 \\
\hline 12.8 & 18.0 & 2.0 & 5.5 & 19.0 & 0 & 0 \\
\hline 12.9 & 40.0 & 6.0 & 8.0 & 32.0 & 0 & 0 \\
\hline 13.1 & 40.0 & 0 & 0 & 0 & 0 & 0 \\
\hline
\end{tabular}

disorder. These observations are, to our knowledge, the first demonstration that hybridomas that synthesize anti-DNA autoantibodies can be obtained from a normal human lymphocyte source. Our observation that the tonsillar lymphocytes of most normal individuals (children and adults) have a high frequency of spontaneous anti-DNA antibody production in vitro predicted the successful fusion of such tonsillar lymphoid cells to the myeloma cell line and the production of a proportion of such hybridomas that produced anti-DNA antibody. The overall frequency of anti-DNA antibody-producing hybridomas (11.8\%) under all culture and fusion conditions was similar to the frequency obtained by Shoenfeld et al. (10), for anti-DNA antibody hybridomas using the same myeloma cell line and pokeweed mitogen-activated circulating SLE lymphocytes. In comparison, a higher frequency $(21 \%)$ was obtained in the present studies, when a 1:1 ratio of myeloma/lymphocytes (unstimulated) was used, which possibly suggests the increased state of spontaneous activation of the lymphoid cells from this tonsillar source. These results also suggest that attention to fusion and culturing conditions might lead to an enhanced yield of specific hybridomas. We have made the assumption here that the tonsillar lymphoid cells in our studies were preactivated, perhaps by the influence of microbial agents in the tonsil on some previous occasion. It is conceivable that an 
Table III. Grouping of Clones According to Reactivity Ratios

\begin{tabular}{|c|c|c|c|c|c|c|c|}
\hline \multirow[b]{3}{*}{ Group } & \multicolumn{6}{|l|}{ Ratio of reactivity } & \multirow{3}{*}{$\begin{array}{l}\text { Clones in } \\
\text { each group }\end{array}$} \\
\hline & \multicolumn{2}{|c|}{$\begin{array}{l}\text { Single-stranded nucleic acid or } \\
\text { analogue }\end{array}$} & \multicolumn{4}{|c|}{ Double-stranded nucleic acid } & \\
\hline & Cardiolipin/ssDNA & RNA/ssDNA & S/N DNA/ssDNA & POLY dG. POLY dC/ssDNA & POLY(dA-dT)/ssDNA & DNA/ssDNA & \\
\hline 1 & 0 & 0 & 0 & 0 & 0 & 0 & KIM 11 \\
\hline 2 & $0.3-0.5$ & 0 & 0 & 0 & 0 & 0 & KIM 10 \\
\hline 3 & 40 & 0 & 0 & 0 & 0 & 0 & KIM 13 \\
\hline 4 & $0.4-0.5$ & 0 & $0.0-0.1$ & 0.3 & 0 & 0.1 & KIM 9 \\
\hline 5 & $0.2-0.5$ & 0 & $0.3-0.4$ & $0.4-0.8$ & $0.5-1.3$ & $0.7-1.3$ & KIM 4 \\
\hline 6 & 0.1 & 0 & 0.2 & 0.5 & 0.2 & 0.2 & KIM 5 \\
\hline $7 a$ & $0.05-0.3$ & $0.1-0.2$ & $0.4-0.9$ & $0.7-2.2$ & $0.4-1.1$ & $0.3-1$ & KIM 7 \\
\hline $7 \mathrm{~b}$ & $0.1-0.2$ & $0.5-0.6$ & 0.6 & 0.8 & 0.6 & 0.4 & KIM 1 \\
\hline 8 & $5.4-40$ & $1-6$ & $0.9-8$ & $3.3-32$ & $0-1.0$ & 0 & KIM 12 \\
\hline
\end{tabular}

even more efficient fusion of these cells might be obtained if additional pokeweed mitogen activation was used with this source of lymphoid cells. It is also possible that a higher yield of anti-DNA antibody-producing hybridomas could have been detected had we screened for nucleic acid antigens other than ssDNA, since some clones that bound strongly to cardiolipin, and poly $\mathrm{dG} \cdot$ poly $\mathrm{dC}$ were barely reactive with ssDNA (KIM $12.5-12.9 ; 13.1)$.

The proof that the hybridomas that we have produced are indeed true hybrids is based on the observation that hybridoma culture supernatants bound to ssDNA and that this antibody was of the IgM class. Neither IgM nor anti-ssDNA antibodies were produced when the myeloma cell line GM 4672 was cultured alone. The possibility of culturing Epstein-Barr virus (EBV)-transformed tonsillar lymphocytes was excluded since the antibody-producing clones showed hyperdiploidy, a feature rarely present in EBV-transformed cells (16). Stronger evidence against EBV transformation, and for true hybridoma production is the observation that the clones expressed not only the HLA antigens of the myeloma cell line but also additional antigens that presumably derived from the tonsillar donor, which indicating a dual origin of the hybrids. Further, the presence of complete killing with all anti-HLA reagents provides evidence

Table IV. Karyotyping of Six Hybridomas

\begin{tabular}{lcll}
\hline Clone & $\begin{array}{l}\text { Hyperdiploid cells } \\
>46 \text { chromosomes }\end{array}$ & $\begin{array}{l}\text { Diploid cells } \\
46 \text { chromosomes }\end{array}$ & $\begin{array}{l}\text { Hypodiploid cells } \\
<46 \text { chromosomes }\end{array}$ \\
\hline KIM 4.1 & $10(20 \%)$ & $32(64 \%)$ & $8(16 \%)$ \\
KIM 4.2 & $4(8 \%)$ & $19(38 \%)$ & $27(54 \%)$ \\
KIM 4.3 & $6(12 \%)$ & $21(42 \%)$ & $23(46 \%)$ \\
KIM 4.4 & $5(10 \%)$ & $13(26 \%)$ & $32(64 \%)$ \\
KIM 4.5 & $10(20 \%)$ & $15(30 \%)$ & $25(50 \%)$ \\
KIM 4.6 & $10(20 \%)$ & $14(28 \%)$ & $26(52 \%)$ \\
\hline
\end{tabular}

for the expression of all of these HLA antigens on each cell. The observation that $100 \%$ cytotoxicity was observed in HLA typing with individual sera in the cloned cells that showed a large percentage of hypodiploidy suggests that chromosome 6 may be preferentially retained in these chromosome-depleted cells.

Karyotypic analysis of the cloned hybridomas showed great chromosomal variation between the clones as well as within them. Others using human-human hybridomas have made similar observations $(10,17)$. This chromosomal instability may account for the inability to clone some of our primary anti-DNA-producing hybridomas.

Similar ratios of ssDNA to DNA binding by supernatants from the primary hybridomas (Fig. 1) and the clones of these hybridomas (Fig. 2) were noted for the majority of hybridomas studied, except KIM 12 and KIM 13. KIM 12 clones did not bind DNA although the primary KIM 12 had an equally good binding to DNA and ssDNA. Furthermore, the original KIM 12 did not show reactivity with cardiolipin (data not presented), although the clones did. KIM 13.1 bound readily to cardiolipin but not to DNA, and binding to ssDNA was almost undetectable. In contrast, its primary hybridoma showed excellent binding to ssDNA and slight reactivity to DNA. The observed discrepancy in antibody specificity between primary hybridomas of KIM 12 and KIM 13 and their respective clones could be due to the presence in the original hybridoma of two fusion products capable of secreting anti-DNA antibodies with different specificities, of which only one was capable of being successfully cloned. It is conceivable that these latter two hybridomas may have undergone somatic mutation and consequently the antiDNA antibody that they produced changed specificity, or that the emergence of new antigenic specificities reflects the expression of a new silent clone.

As presented in Fig. 2, we have detected a broad spectrum of anti-DNA antibody specificities that resulted from the fusion of myeloma and tonsillar lymphoid cells from a normal donor. 
A similar broad range of anti-DNA antibody specificities has been reported to exist in the serum of SLE patients as well as in the supernatants prepared from hybridomas of human and murine SLE origin $(10,18,19)$. It is not yet clear what epitope these antibody molecules recognize. As proposed for SLE monoclonal anti-DNA antibodies, the sugar-phosphate backbone common to both nucleotides and cardiolipin could represent a common determinant for recognition by these antibodies. However, this explanation does not account for the specificities of groups 2 and 3 (Table III) in which there is reactivity with cardiolipin but not with DNA or RNA; or in group 8 in which reactions do not occur with DNA at all. Clones in groups 2 and 3 show some common binding to both cardiolipin and ssDNA. This could indicate that the deoxysugar of DNA and a conformation provided by randomly coiled or denatured DNA could be important in establishing the determinant common to both DNA and cardiolipin. Cardiolipin may not have a fixed conformation, but rather some flexibility that allows it to conform and bind to different anti-DNA antibody-binding sites. The cardiolipin conformation also may depend on the interaction with other cardiolipin molecules, and with the plastic at the plastic-liquid interface. Group 1 hybridomas would appear to produce antibodies in which the binding site is such as to preclude any of the conformations of cardiolipin.

There is no example in the clones studied of anti-DNA antibody reacting towards low molecular weight S/N DNA alone. This may be an indication that immunogenic low molecular weight DNA (14) may be derived from nonimmunogenic high molecular weight DNA that contains the same determinants. An exception was noted for group 8 hybridomas, which show reactivity to S/N DNA but not to DNA, however, groups 7 and 8 are distinguished by the fact that they bind to RNA. This suggests that the primary epitope recognized by the antibodies in these groups may be RNA rather than DNA.

Since both poly $(\mathrm{dA}-\mathrm{dT})$ and poly $\mathrm{dG} \cdot$ poly $\mathrm{dC}$ are expected by the Watson and Crick model to have the same double helical structure in the central region of the polymer, the general preference for poly $\mathrm{dG} \cdot$ poly $\mathrm{dC}$ of antibodies from groups $4,6,7$, and 8 may reflect a specificity for terminal ends of the nucleic acids and presumably terminal ends with guanine and/or cytosine.

Alternatively, it is possible that differing antibody specificities for the two synthetic polymers results from unique supercoiled structures dictated by the base composition. However, it is premature to state whether GC-rich regions are determinants for anti-DNA antibody production, and whether there is any significance for the development of autoimmune anti-DNA antibodies in either the enhanced thermodynamic stability of double strands rich in GC or the closeness of GCrich regions to the sites for initiation of replication of some viral strands. Some authors have suggested high GC content in DNA molecules found in DNA-anti-DNA antibody complexes (20) and in low molecular weight DNA fragments in lymphocytes of patients with SLE (21).
The present study implies that immunoglobulin genes coding for anti-DNA autoantibodies exist in the lymphocytes of normal individuals. These genes may have a common ancestral origin with anti-DNA antibody genes of SLE lymphocytes since these antibodies display similar antigenic binding specificities. These studies also provide base-line data on antiDNA antibody production by recently constructed hybrids of a myeloma line and normal tonsillar lymphocytes. The spectrum of antibody specificities detected will be followed with time to determine the stability of the binding specificities. It will also be of interest to compare the anti-DNA antibody of SLE and normals through idiotype analysis with antiidiotype probes.

\section{Acknowledgments}

We are grateful to Dr. Joyce Rauch for her expert advice on hybridoma production and for her help with the cell fusion. We also thank Mrs. Marlyn French for typing the manuscript.

This work was supported by a grant from The Arthritis Society, Canada.

\section{References}

1. Talal, N., and A. D. Steinberg. 1974. The pathogenesis of autoimmunity in New Zealand black mice. Curr. Top. Microbiol. Immunol. 64:79-103.

2. Swaak, A. G. J., L. A. Aarden, L. W. Statius van Eps, and T. E. W. Feltkamp. 1979. Anti-dsDNA and complement profiles as prognostic guides in systemic lupus erythematosus. Arthritis Rheum. 22:226-235.

3. Koffler, D., V. Agnello, and H. G. Kunkel. 1974. Polynucleotide immune complexes in serum and glomeruli of patients with systemic lupus erythematosus. Am. J. Pathol. 74:109-122.

4. Koffler, D., R. I. Carr, V. Agnello, R. Thoburn, and H. G. Kunkel. 1971. Antibodies to polynucleotides in human sera. Antigenic specificity and relation to disease. J. Exp. Med. 134:294-312.

5. Hughes, G. R. V., A. S. Cohen, and C. L. Christian. 1971. AntiDNA activity in systemic lupus erythematosus. A diagnostic and therapeutic guide. Ann. Rheum. Dis. 30:259-264.

6. Roder, J. C., D. A. Bell, and S. K. Singhal. 1978. Regulation of the autoimmune plaque-forming cell response to single-strand DNA (sDNA) in vitro. J. Immunol. 121:38-43.

7. Hoch, S., P. H. Schur, and J. Schwaber. 1983. Frequency of anti-DNA antibody producing cells from normals and patients with systemic lupus erythematosus. Clin. Immunol. Immunopathol. 27:2834.

8. Cairns, E., and D. A. Bell. 1983. Anti-DNA antibody responses in cultures of circulating SLE or normal lymphoid cells or normal tonsillar lymphoid cells. Arthritis Rheum. 26(4)S72:Abstr D26.

9. Shoenfeld, Y., S. C. Hsu-Lin, J. E. Gabriels, L. E. Silberstein, B. C. Furie, B. Furie, B. D. Stollar, and R. S. Schwartz. 1982. Production of autoantibodies by human-human hybridomas. J. Clin. Invest. 70:205-208.

10. Shoenfeld, Y., J. Rauch, H. Massicotte, S. K. Datta, J. AndreSchwartz, B. D. Stollar, and R. S. Schwartz. 1983. Polyspecificity of monoclonal lupus autoantibodies produced by human-human hybridomas. N. Engl. J. Med. 308:414-420. 
11. Boyum, A. 1968. Isolation of mononuclear cells and granulocytes from human blood. Scand. J. Clin. Lab. Invest. 21,S97:77-89.

12. Littlefield, J. W. 1964. Selection of hybrids from matings of fibroblasts in vitro and their presumed recombinants. Science (Wash. DC). 145:709-710.

13. Doty, P., J. Marmur, J. Einger, and C. Schildkraut. 1960 Strand separation and specific recombination in deoxyribonucleic acids: physical chemical studies. Proc. Natl. Acad. Sci. USA. 46:461476.

14. Pancer, L. B., M. F. Millazo, V. L. Morris, S. K. Singhal, and D. A. Bell. 1981. Immunogenicity and characterization of supernatant DNA released by murine spleen cells. J. Immunol. 127:98-104.

15. Terasaki, P. I., D. Bernoco, M. S. Park, G. Ozturk, and Y. Iwaki. 1978. Microdroplet testing for HLA-A,B,C and D antigens. Am. J. Clin. Pathol. 69:103-120.

16. Nilsson, K., and J. Ponten. 1975. Classification and biological nature of established human hematopoietic cell lines. Int. J. Cancer. 15:321-341.
17. Edwards, P. A. W., C. M. Smith, A. Munro Neville, and M. J. O'Hare. 1982. A human-human hybridoma system based on a fast growing mutant of the ARH-77 plasma cell leukemia-derived line. Eur. J. Immunol. 12:641-648.

18. Lafer, E. M., J. Rauch, C. Andrzejewski, Jr., D. Mudd, B. Furie, B. C. Furie, R. S. Schwartz, and B. D. Stollar. 1981. Polyspecific monoclonal lupus autoantibodies reactive with both polynucleotides and phospholipids. J. Exp. Med. 153:897-909.

19. Andrzejewski, C. Jr., J. Rauch, E. Lafer, D. Stollar, and R. S. Schwartz. 1980. Antigen-binding diversity and idiotypic cross-reactions among hybridoma autoantibodies to DNA. J. Immunol. 126:226-231.

20. Sano, H., and C. Morimoto. 1982. DNA isolated from DNA/ anti-DNA antibody immune complexes in systemic lupus erythematosus is rich in guanine-cytosine content. J. Immunol. 128:1341-1345.

21. Sano, H., M. Imokawa, A. D. Steinberg, and C. Morimoto. 1983. Accumulation of guanine-cytosine-enriched low M.W.DNA fragments in lymphocytes of patients with systemic lupus erythematosus. J. Immunol. 130:187-190. 